\title{
AKTIVITAS DAN RELASI SOSIAL MAJELIS AGAMA BUDDHA TANTRAYANA ZHENFO ZONG KASOGATAN DI KALIMANTAN BARAT
}

\author{
M. TAUFIK HIDAYATULLOH*
}

\begin{abstract}
Abstrak
Penelitian ini dilaksanakan di Kalimantan Barat pada Tahun 2015. Subjek penelitian adalah pengurus Majelis Agama Buddha Tantrayana Zhenfo Zong Kasogatan Indonesia Kalimantan Barat, Kantor Kementerian Agama Kalimantan Barat (Pembimas Buddha, Penyelenggara Bimbingan Masyarakat Kota Pontianak dan Kabupaten Kubu Raya), Forum Kerukunan Umat Beragama Kalimantan Barat, Tokoh agama maupun pengurus Majelis aliran lainnya yang dipilih secara purposive. Jumlah responden dalam penelitian ini berjumlah 12 orang. Teknik pengumpulan data yang digunakan adalah wawancara mendalam dengan berbagai informan, dan penelusuran dokumen. Data dianalisis dengan menggunakan teknik yang dikemukakan oleh Miles dan Huberman, yakni reduksi data (pemilahan, pemusat perhatian), penyajian (display) data dan penarikan kesimpulan.

Hasil penelitian menunjukkan bahwa; (1) Majelis Agama Buddha Tantrayana Zhenfo Zong Kasogatan sudah memiliki kecukupan sarana maupun prasarananya baik berkaitan dengan tempat ibadah, pembinaan umat Buddha dan pembinaan anak-anak dan kesejahteraan umat Buddha, dan (2) Tercatat beberapa gesekan / konflik yang terjadi yaitu ; konflik dalam bidang pendidikan dan konflik akibat konversi agama. Relasi sosial ummat Buddha dengan masyarakat masih terbatas pada bidang-bidang tertentu. Sedangkan relasi dengan pemerintah menunjukkan hubungan yang erat.
\end{abstract}

\section{KaTA KUNCI:}

Umat Buddha, Konflik, Relasi Sosial

\section{Abstract}

This study aims at firstly reporting the activities and organization structure of Tantrayana Zhenfo Kong Budhha forum Kasogatan Indonesia in West Borneo. Secondly, it is explaining the internal conflicts among Buddhists and the resolutions. The study was conducted in West Borneo in 2015 by involving the Tantrayana Zhenfo Kong Budhha forum, regional ministry office (Buddha division, community counseling of Pontianak city and Kubu Raya regency), Forum of Interreligious relation (FKUB) of West Borneo, some religious figures, and forum administrators. 12 researchers conducted this study. Data were collected through in-depth interviews and documentary study. The data were analyzed by following Miles and Huberman's sequences, namely data reduction, data display, and conclusion.

The results of this study indicate that the Budhha forum of Tantrayana Zhenfo Kong Kasogatan Indonesia has sufficient facilities in terms of houses of worship, Buddhist counseling, and children care. Additionally, it is found that there are some emerging conflicts, such as: conflicts in education and conflicts of conversion. In terms of social relationship with local people, Buddhists in west Borneo are involved in social gathering for only particular events. On the other hands, they have a relatively close relationship with the government.

\section{KeY WORDS:}

Buddhist, Conflict, Social Relation

\footnotetext{
"Penyuluh Agama Islam Kemenag Kab. Bogor, Jl. Bersih No. 1, Komplek Pemda Cibinong Bogor, email; taufikmtht@yahoo.co.id ** Naskah diterima Agustus 2015, direvisi Oktober 2015, disetujui untuk dimuat November 2015.
} 


\section{A. Pendahuluan}

\section{Latar Belakang Masalah}

Menurut Durkheim, agama adalah realitas sosial dan kekuatan kolektif masyarakat yang berada di atas individu-individu, sehingga para pemeluknya tunduk dan bergantung pada kekuatan moral daripadanya, menerima segala sesuatu yang baik dan meninggalkan larangannya ${ }^{1}$, sehingga agama dipahami sebagai jalan menuju kehidupan sejati, yang diyakini setiap pemeluknya dan menjadi pedoman atau lentera dalam hidupnya. Watak dasarnya adalah memperbaiki realitas kehidupan yang ada (das sein) agar sesuai dengan kehidupan seharusnya (das sollen). Jika suatu kelompok individu dan masyarakat secara sosial semakin tunduk dan mematuhi ajaranya, berarti agama itu bermakna tinggi dan berfungsi baik. Sebaliknya jika individu atau masyarakat secara sosial tidak lagi tunduk pada ajaran agamanya, berarti agama itu sudah kehilangan makna, apalagi berfungsi, sehingga beragamapun sekedar pengakuan administratif belaka.

Agama Buddha merupakan agama tua yang kedatangannya bersamaan dengan Hindu di Indonesia. Pada masa Majapahit, agama Buddha dengan agama Hindu dapat hidup berdampingan secara damai ${ }^{2}$. Sebagai bukti, sejumlah warisan kejayaan kerajaan Hindu dan Buddhapun dapat ditemukan di seluruh Indonesia, seperti candi dan berbaga situs sejarah yang menceriterakan perhatian raja terhadap agama Syiwa Buddha. Patung-patung dan prasasti sebagai situs sejarah kerajaan Hindu Buddha sebagai simbol bahwa agama Hindu Buddha pernah mendominasi kehidupan sosial keagamaan masyarakat, bertebaran merata di seluruh pelosok Nusantara, sebelum akhirnya digantikan dengan Islam.

Perkembangan agama Buddha dicirikan dengan perkembangan dinamika ummatnya, diiringi dengan perkembangan berbagai aliran atau sekte seperti ; Theravada, Mahayana dan Tantrayana. Di samping itu banyak majelis yang dikelola oleh komunitas beragama Buddha di seluruh Indonesia, baik itu bersekte Theravada, Mahayana maupun Tantrayana. Seperti

\footnotetext{
${ }^{1}$ Bernard Raho SVD, Agama dalam Perspektif Sosiologi (Jakarta : Penerbit Obor, 2013), 44.

${ }^{2}$ Buddha Dharma Education Association. 2008. "Buddhism in Indonesia". Dalam http:// www.buddhanet.net/e-learrning/ buddhistworld/indo-txt.htm [Diunduh 23 April 2015].
}

dijelaskan oleh Dirjen Bimas Buddha, sekte Mahayana berkembang pesat di China, Korea dan Jepang. Theravada/Hinayana (mazhab yang berusaha tetap seperti ajaran Buddha Gautama/ fundamentalis) masih bertahan di Srilangka, dan Birma. Sementara itu Tantrayana berkembang di Tibet. Beberapa sekte dibawah Mahayana adalah Maetriya yang berkembang di Taiwan dan Nicheren berkembang di Jepang ${ }^{3}$. Begitu banyak sekte dan aliran sehingga dalam mazhab Mahayana masih terbagi menjadi sekitar 18 sekte, Budhayana terdiri dari 14 sekte, Tridarma sebagai gabungan Buddha, Khonghuchu dan Tao (Loutse) dan seterusnya.

Sekte dan majelis dalam suatu agama merupakan sebuah sunatullah (hukum alam). Keberbedaan yang muncul kerap kali menyulut persinggungan yang bisa memantik konflik demi untuk menyingkirkan yang berbeda. Potensi konflik yang dapat memuncak setidaknya dapat diantisipasi dengan cara menemukenali berbagai aliran atau sekte tersebut. Atas dasar inilah, maka dirasakan perlu melakukan kajian lapangan, sehingga diketahui gerakan dan aktivitasnya dalam upaya tetap menjaga keharmonisan kehidupan bermasyarakat, berbangsa dan bernegara.

\section{Masalah, Tujuan dan Kegunaan Penelitian}

1. Masalah Penelitian

Berdasarkan latar belakang di atas, maka permasalahan yang akan dikaji adalah: Bagaimana manajemen organisasi dan aktivitas Majelis Tantrayana Kasogatan Indonesia? Bagaimana dinamika atau konflik-konflik intern yang pernah terjadi dan cara penyelesaiannya ? dan Bagaimana hubungannya dengan pemerintah dan masyarakat setempat?

\section{Tujuan Penelitian}

Tujuan yang ingin dicapai, yaitu untuk; mengetahui manajemen organisasinya (struktur, keanggotaan), dan aktivitasnya (pembinaan, dana dan sarananya); konflik-konflik intern yang

\footnotetext{
${ }^{3}$ Dirjen Bimas Agama Buddha, Bahan pengayaan dalam rangka penyusunan Desain Operasional Penelitian oleh Puslitbang Kehidupan Keagamaan 2015; lihat pula penjelasan Jo Pristiana dalam brain storming bahan penyusunan desain penelitian ini; lihat pula Power Point oleh Dirjen Bimas Agama Buddha, dalam brain storming untuk melengkapi bahan penyusunan desain operasional penelitian, Maret 2015.
} 
pernah terjadi dan cara penyelesaiannya, serta hubungannya dengan pemerintah dan masyarakat setempat.

\section{B. Metode Penelitian}

Penelitian ini merupakan penelitian eksploratif, dimana peneliti menggali informasi tentang keberadaan majelis Tantrayana Kasogatan Indonesia. Dalam menggambarkan realitas sosial, penelitian ini bersifat deskriptif analitik, sehingga data yang dipaparkan betulbetul merupakan serangkaian fenomena dan kenyataan yang memiliki hubungan langsung dengan keberadaan agama Buddha aliran Kasogatan.

Penelitian dilaksanakan di Kalimantan Barat pada Tahun 2015. Subjek penelitian adalah para narasumber yang terdiri dari pimpinan Majelis Kasogatan, pimpinan agama, penganut agama Buddha aliran Kasogatan, Kantor Kementerian Agama Kabupaten Kubu Raya/Kota Pontianak, pemerintah daerah, dan masyarakat sekitar. Beberapa pihak berhasil diwawancarai yang berasal dari; unsur pimpinan Majelis Kasogatan (Kabupaten Kubu Raya dan Kota Pontianak), Kepala Kantor Kementerian Agama (Kota Pontianak), Pengurus Walubi (Pimpinan wilayah yang berkedudukan di Provinsi Kalimantan Barat ataupun Pimpinan Daerah yang berkedudukan di Kota/Kabupaten), Tokoh agama non Buddha, Forum Kerukunan Umat Beragama Kalimantan Barat dan Akademisi.

Pemilihan narasumber yang diwawancarai tersebut dipilih secara ditentukan dengan beberapa pertimbangan seperti: tokoh agama yang dianggap mengetahui eksistensi Majelis Kasogatan, seseorang yang ditokohkan pada lembaga, institusi atau organisasi kemasyarakatan atau keagamaan. Teknik pengumpulan data yang digunakan adalah wawancara mendalam dengan berbagai informan dan penelusuran dokumen. Data dianalisis dengan menggunakan teknik yang dikemukakan oleh Miles dan Huberman, yakni reduksi data (pemilahan, pemusat perhatian), penyajian (display) data dan penarikan kesimpulan.

\section{Sejarah Majelis Agama Buddha Tantrayana Zhenfo Zong Kasogatan INDONESIA KALIMANTAN BARAT Latar Belakang Pendirian Majelis Kasogatan}

Pendiri aliran Tantrayana Zhenfo Zong bernama Liansheng Huo Fo atau disebut juga dengan Lu Sheng Yen (sering disebut sebagai Maha Acarya Lian Sheng). Ia adalah seorang warga Amerika Serikat keturunan Tionghoa. Di mulai dari Amerika Serikat inilah, Agama Buddha aliran Tantrayana Zhenfo Zong Kasogatan mulai menyebar ke seantero dunia, termasuk ke Indonesia. Di Indonesia, Agama Buddha aliran Tantrayana Zhenfo Zong Kasogatan mulai menyebar ke berbagai provinsi, termasuk ke Kalimantan Barat.

Di Kalimantan Barat, berdirinya Majelis Agama Buddha Kasogatan sekitar tahun 1985an ke Singkawang dan kemudian ke Pontianak di tahun 1987-an. Masuknya aliran Tantrayana Kasogatan di Kalimantan Barat terjadi karena beberapa jalur. Pertama, beberapa umat Buddha ada yang membaca buku tulisan Maha Acarya Lian Sheng, kemudian mengangkat guru bersama (bersarana) kepadanya. Kedua, adanya hubungan antara Majelis Kasogatan pusat dengan beberapa umat Buddha di Kalimantan Barat, dan Ketiga, melihat beberapa aliran lain mendirikan majelis, maka ada inisiatif (lebih dekat dengan ikut-ikutan) dari beberapa tokoh agama Buddha yang telah bersarana kepada Maha Acarya Lian Sheng untuk mendirikan juga majelis agama yang akan menaungi dan membina umat yang telah menganut aliran Kasogatan ${ }^{5}$.

\section{Proses Pendirian Majelis Kasogatan}

Sebagaimana pada umumnya aliran yang baru masuk ke sebuah daerah, mula-mula umat Buddha mengadakan puja bakti di rumahrumah, kemudian menyelenggarakan ritual sendiri dengan cara meminjam Vihara Sakyamuni di tahun 1987 selama kurang dari 20 tahun. Setelah itu sejak tahun 1999 mulai membangun sebuah vihara besar di Jalan Ahmad Yani II dan selesai tahun 2004. Vihara tersebut bernama Vihara Vajra Bumi Kertayuga (penuh dengan pahala sejati laksana intan) seluas 1.800 meter persegi yang mengadopsi bentuk Vihara Tibet.

Sejak masuknya Majelis Agama Buddha Kasogatan ke Kalimantan Barat tahun 1985-an,

\footnotetext{
${ }^{4}$ Muhammad Idrus, Metode Penelitian Ilmu Sosial : Pendekatan Kualitatif dan Kuantitatif (Jakarta : Erlangga, 2009), 147-148.

${ }^{5}$ Wawancara dengan Pandita Rudy Cahyadi Lim sebagai Pandita Lokapalasraya Vihara Vajra Bhumi Kertayuga, 21 April 2015.
} 
organisasi majelis solid dalam mengatur dan membina umat Buddha aliran Tantrayana Kasogatan. Namun memasuki tahun 1998, akibat konflik kepengurusan, ada sebagian anggota Majelis Agama Buddha Kasogatan Kalimantan Barat yang memisahkan diri dan membentuk organsiasi baru dengan nama Majelis Agama Buddha Tantrayana Indonesia (Madhatantri) ${ }^{6}$. Tempat ibadahpun berpisah ketika tahun 1991 didirikan Vihara Buddha Vajra, yang beralamat di Jalan Siam Gang Kelantan IV No162 Pontianak dalam rangka mewadahi kepentingan beribadah umatnya. Dengan demikian, di Kalimantan Barat terdapat dua organisasi yang menjadi wadah dari umat Buddha aliran Tantrayana, yaitu Majelis Agama Buddha Tantrayana Zhenfo Zong Kasogatan Indonesia (lebih dikenal dengan nama Kasogatan) dan Majelis Agama Buddha Tantrayana Indonesia (lebih dikenal dengan nama Madhatantri).

Jumlah vihara yang menjadi tempat ibadah umat Buddha Tantrayana Zenfo Zong Kasogatan Indonesia (selanjutnya untuk memudahkan penyebutan akan menggunakan nama Kasogatan) bisa dikatakan masih sedikit. Saat ini di seluruh wilayah Kalimantan Barat baru terdapat 6 buah vihara yang tersebar di empat kabupaten/kota, yaitu 1 vihara di Kabupaten Kubu Raya - ini merupakan vihara paling besar, 3 vihara di Kabupaten Landak, 1 vihara di Kota Singkawang dan 1 vihara di Kabupaten Sambas. Jumlah keseluruhan vihara di bawah naungan aliran Buddha Kasogatan di Kalimantan Barat sebanyak 6 buah vihara.

Anggota aliran Kasogatan di Kalimantan Barat sejauh ini belum dapat diketahui jumlahnya. Selain karena tidak adanya data ${ }^{7}$, juga disebabkan oleh jumlah umat yang beribadah di vihara tidak mewakili jumlah keseluruhan umat Buddha Kasogatan ${ }^{8}$. Untuk anggota Vihara Vajra Bumi Kertayuga di Kubu Raya, diperoleh informasi ada 200 orang anggota

\footnotetext{
${ }^{6}$ Nuhrison M Nuh, Respon Masyarakat terhadap Aliran dan Paham Keagamaan Kontemporer di Indonesia (Jakarta: Puslitbang Kehidupan Keagamaan, Badan Litbang dan Diklat, Kementerian Agama RI, 2012), 23.

${ }^{7}$ Wawancara dengan Eddo sebagai Pengurus Muda Mudi Vihara Vajra Bhumi Kertayuga, 20 April 2015.

${ }^{8}$ Wawancara dengan Pandita Rudy Cahyadi Lim sebagai Pandita Lokapalasraya Vihara Vajra Bhumi Kertayuga, 21 April 2015.
}

yang aktif ibadah setiap hari minggu. Jumlah anggota yang hadir saat ibadah tahunan cenderung meningkat terutama menjelang imlek hingga mencapai 1.000 orang. Dilihat dari sisi etnis, bahwa umat Buddha Kasogatan beretnis Tionghoa sebanyak 89\%, Dayak 10\% dan etnis lainnya $1 \%$.

Dilihat secara umum bahwa aliran Kasogatan di Kalimantan Barat diperkirakan menempati peringkat ke tiga pemeluk terbesar setelah peringkat pertama diduduki oleh aliran Mapanbumi (Maitreya) dan kedua oleh Magabudhi (Theravada) ${ }^{10}$. Baik Maitreya, Theravada dan Tantrayana termasuk ke dalam Mahayana yang ternyata menjadi umat Buddha yang mayoritas. Hal ini disebabkan oleh kemudahan mempraktekkannya ${ }^{11}$ dan pengajaran yang menggunakan bahasa Indonesia $^{12}$. Secara lebih khusus lagi bahwa umat Buddha aliran Kasogatan dipandang cepat perkembangnnya karena didukung oleh kemampuan pengurus yang rata-rata memahami manajemen ${ }^{13}$.

\section{Kegiatan Majelis Tantrayana ZHENFo Zong Kasogatan IndONESIA Kalimantan Barat}

\section{Fungsi Tugas Struktur Majelis Agama Buddha Tantrayana Zhenfo Zong Kasogatan Indonesia di Kalimantan Barat}

Struktur Majelis Tantrayana Kasogatan Indonesia Kalimantan Barat terdapat beberapa organ organisasi yang terdiri atas; Yayasan Vajra Bumi Kertayuga dipimpin Lie Min Fhung sebagai ketua dan Firmanto, SH sebagai sekretaris, Vihara Vajra Bumi Kertayuga pimpinan Yo Sai Heng, Lotus Light Charity dipimpin oleh Tansil Halim dan Pandita Rudy Cahyadi, dan Sekolah minggu Vihara Vajra Bumi Kertayuga dengan Eddo

\footnotetext{
${ }^{9}$ Wawancara dengan Pandita Hendra, ST sebagai Wakil Sekretaris Majelis Agama Buddha Tantrayana Zhenfo Zong Kasogatan Indonesia Kalimantan Barat, 16 April 2015.

${ }^{10}$ Wawancara dengan Pandita Hendra, ST sebagai Wakil Sekretaris Majelis Agama Buddha Tantrayana Zhenfo Zong Kasogatan Indonesia Kalimantan Barat, 16 April 2015.

${ }^{11}$ Wawancara dengan Rakiman, S.Thi sebagai Penyelenggara Bimas Buddha Kabupaten Kubu Raya, 25 April 2015.

${ }^{12}$ Wawancara dengan Budi sebagai Pengurus Majelis agama Buddha Mapanbumi Kota Pontianak, 22 April 2015.

${ }^{13}$ Wawancara dengan Rakiman, S.Thi sebagai Penyelenggara Bimas Buddha Kabupaten Kubu Raya, 25 April 2015.
} 
sebagai kepala sekolah minggu.

Berdasarkan susunan pengurus organisasi di lingkungan Kasogatan baik dilihat dari pengurus Majelis Agama Buddha Tantrayana Zhenfo Zong Kasogatan Indonesia Provinsi Kalimantan Barat dan pengurus Vihara Vajra Bhumi Kertayuga ternyata banyak kepengurusan ganda di antara para pengurusnya, hal ini disebabkan keterbatasan sumber daya manusia yang memiliki kemauan dan kemampuan berorganisasi memajukan pembinaan umat Buddha Kasogatan.

Adanya organisasi dan organ pelengkapnya meniscayakan adanya umat. Berbicara tentang persebaran umat Buddha Tantrayana Zenfo Zong Kasogatan di seluruh wilayah Kalimantan Barat baru masih terbatas pada beberapa kabupaten/ kota, maka Majelis Agama Buddha Tantrayana Zhenfo Zong Kasogatan Indonesia tingkat kabupaten/kota, tersebar di empat daerah, yaitu Kabupaten Kubu Raya, Kabupaten Landak, Kota Singkawang dan Kabupaten Sambas.

Rekrutmen anggota yang dijalankan oleh Majelis Agama Buddha Tantrayana Zhenfo Zong Kasogatan Indonesia Provinsi Kalimantan Barat terdiri dari 4 cara, yaitu ; Merekrut anggota baru pada upacara tahunan karena umat membawa relasi dan manfaatnya karena ada testimoni sebanyak 50 \%-an, Darma duta pada saat sembahyang duka sebanyak $30 \%$-an, Buku karangan Mahaacarya 20 \%-an dan Sekolah minggu sebanyak $1 \%$-an.

\section{Kegiatan Pembinaan Majelis Agama Buddha Tantrayana Zhenfo Zong Kasogatan Indonesia di Kalimantan Barat}

Untuk meningkatkan kualitas beragama umat, kegiatan pembinaan mutlak dilakukan yang selama ini dilakukan dengan cara: Konsultasi, baik kepada Acarya-tergantung kedatangan minimal 4 kali dalam setahun maupun kepada Bikkulama. Tema yang diusung ketika konsultasi ke Acarya adalah tentang usaha, kesehatan ataupun perjodohan. Adapun tema konsultasi kepada Bikkulama berkisar pada tata cara ibadah, Ceramah dharma seminggu dua kali setelah selesai kebaktian, dan Kelas Dharma oleh Acarya.

3. Pendanaan dalam Majelis Agama Buddha Tantrayana Zhenfo Zong Kasogatan Indonesia

\section{di Kalimantan Barat}

Roda organisasi majelis maupun organorgannya memerlukan dana untuk menggerakkannya. Adapun dana diperoleh melalui beberapa jalan, yaitu; melalui koperasi yang melayani keperluan peribadatan, kegiatan penyewaan fasilitas pendukung ibadah maupun fasilitas umum, kegiatan dana dari kegiatan upacara dan sumbangan sukarela. Secara detail, pendanaan berasal dari; upacara, koperasi, penyewaan tempat abu, sumbangan sukarela, pendaftaran dewa tahunan, peringatan Dewi Kwan Im, pemasangan lampion di vihara, menyewakan stand atau space iklan di pasar imlek, derma tahunan sebesar Rp. 25.000,- yang diberikan pada bendahara vihara, dan dana paramitha.

\section{Sarana dan Prasarana dalam Majelis Agama Buddha Tantrayana Zhenfo Zong Kasogatan Indonesia di Kalimantan Barat}

Selain sarana berbagai organ organisasi majelis, Majelis Agama Buddha Tantrayana Zenfo Zong Kasogatan Indonesia juga dilengkapi oleh vihara pusat bernama Vihara Vajra Bhumi Kertayuga, juga vihara yang tersebar di berbagai kabupaten dan kota, di antaranya; 3 vihara di Kabupaten Landak, 1 vihara di Kota Singkawang dan 1 vihara di Kabupaten Sambas.

\section{Relasi Sosial Inter dan Antar Agama}

Pengurus majelis sebagaimana organisasi pada umumnya mengisi berbagai jabatan seperti ketua, wakil ketua, sekretaris, bendahara dan berbagai ketua bidang. Semua jabatan tersebut diadakan dalam rangka memudahkan pembagian kerja di antara pengurus bersangkutan. Hubungan antar anggota pengurus majelis Kasogatan diluar penyelenggaraan musyawarah bersifat kembali seperti biasa tanpa ada perbedaan. Artinya, sesama pengurus dapat melakukan hubungan informal.

Relasi sosial Majelis Kasogatan dengan majelis lainnya berjalan cukup baik. Hubungan antar majelis terjadi saat ulang tahun vihara dari aliran tertentu akan mengundang dari perwakilan aliran lainnya ${ }^{14}$. Hubungan antar aliran juga terjadi saat memperingati Waisak dimana seluruh aliran diminta untuk masuk menjadi panitia perayaan

${ }^{14}$ Wawancara dengan Pandita Hendra, ST sebagai Wakil Sekretaris Majelis Agama Buddha Tantrayana Zhenfo Zong 
WAISAK bersama ${ }^{15}$. Belum lagi tentang perwakilan agama Buddha dalam masalah kerukunan hidup beragama yang tergabung dalam FKUB ternyata seluruh aliran satu suara dan mempercayakan sepenuhnya kepada perwakilan umat Buddha apapun alirannya. Meski demikian, masing-masing aliran sangat tertutup sehingga mereduksi kemungkinan interaksi ajaran dengan aliran lain ${ }^{16}$.

Menyangkut pergaulan di antara masyarakat biasa (antar penganut agama), penganut agama Buddha Kasogatan tidak terlalu terbuka. Ummat Buddha yang kebanyakan beretnis Tionghoa kurang dapat bergaul dengan non Tionghoa, kalau ada orang asing yang masuk ke sebuah gang contohnya, maka mereka cenderung curiga dan tertutup ${ }^{17}$. Namun demikian dikecualikan bila pergaulannya berbentuk kerjasama usaha ${ }^{18}$, ketika merayakan hari raya ${ }^{19}$ dan melakukan ngembun [ronda malam] dalam pergaulan kewargaan ${ }^{20}$.

Secara eksternal, saling menghormati antar pemeluk agama terjadi terutama dengan penduduk Tionghoa saat malam imlek dilakukan kaum Kristiani dengan cara melaksanakan ibadah syukur menjelang imlek. Sementara itu, hubungan dengan Muslim sejauh ini masih kondusif di tengah adanya kekhawatiran akan efek tindakan umat Buddha di Myanmar yang melakukan diskriminasi terhadap umat minoritas dapat mempengaruhi relasi sosial (aksi balasan) di Kalimantan Barat.

Relasi sosial antara aliran Kasogatan yang diwakili oleh Majelis Kasogatan dengan pemerintah juga berjalan dengan baik. Hal tersebut dibuktikan dengan kehadiran perwakilan pemerintah baik dari pemerintah daerah maupun Kemenag dalam berbagai acara seperti pelantikan pengurus WALUBI ataupun

Kasogatan Indonesia Kalimantan Barat, 16 April 2015.

${ }^{15}$ Wawancara dengan Pandita Edy Tansuri sebagai Ketua WALUBI Kalimantan Barat, 18 April 2015.

${ }^{16}$ Wawancara dengan Pandita Edy Tansuri sebagai Ketua WALUBI Kalimantan Barat, 18 April 2015.

${ }^{17}$ Wawancara dengan Pendeta Ir. Iwan Luwuk sebagai Wakil Sekretaris FKUB Kota Pontianak / Pendeta Gereja Pantekosta Indonesia Barat Kota Pontianak, 24 April 2015.

${ }^{18}$ Wawancara dengan Rakiman, S.Thi sebagai Penyelenggara Bimas Buddha Kabupaten Kubu Raya, 25 April 2015.

${ }^{19}$ Wawancara dengan Budi sebagai Pengurus Majelis Agama Buddha Mapanbumi Kota Pontianak, 22 April 2015.

${ }^{20}$ Wawancara dengan Budi sebagai Pengurus Majelis Agama Buddha Mapanbumi Kota Pontianak, 22 April 2015. kegiatan lainnya.

\section{Kegiatan Sosial Keagamaan}

Adanya dana yang terkumpul memungkinkan dilakukannya pendistribusian kepada umat yang membutuhkan. Tercatat beberapa kegiatan telah dilaksanakan sejak beberapa tahun yang lalu. Salah satu kinerja organisasi majelis yang cukup menonjol adalah bantuan sosial kepada masyarakat yang membutuhkan. Beberapa bentuk bantuan sosial ini adalah; bantuan sembako pada hari Waisak yang dilakukan majelis rutin per tahunnya, bantuan sembako kepada panti jompo dan yatim piatu secara rutin dilakukan oleh vihara setiap bulan, bantuan sosial kunjungan ke rumah umat, pengobatan juga kebaktian singkat dan do'a oleh Lotus Light Charity.

\section{Konflik yang Pernah Terjadi}

Sejauh ini belum ada konflik yang memasuki tahapan agresi (kekerasan yang berhadapan dengan kekerasan) baik antar aliran dalam agama Buddha maupun antar agama Buddha dengan berbagai agama lainnya. Meskipun demikian, tercatat beberapa gesekan yang terjadi utamanya antara umat Buddha dengan umat Kristiani. Pertama, terkait dengan perilaku seorang oknum pendeta yang pernah melakukan upaya pembakaran rupang dari salah satu vihara aliran Mapanbumi/LKBI/BDI sekitar tahun 2010, akibat adanya anggapan bahwa rupang adalah berhala yang harus dilenyapkan dengan dibakar.

Kedua, konflik dalam bidang pendidikan. Pernah ada kasus di salah satu SD di mana kepala sekolah beragama Katolik namun mengajak siswa beragama Buddha untuk belajar agama Katolik meski di sana ada juga guru agama Buddha. Kasus lainnya terjadi di salah satu SMP, siswa diminta mengisi surat pernyataan untuk mengikuti pelajaran agama Kristen/Katolik padahal menurut UU Sisdiknas bahwa bila tidak ada guru agama di sekolah yang sama dengan agama siswa, maka siswa dapat dididik oleh guru agama yang berada di luar sekolah ${ }^{21}$. Upaya konversi agama Buddha ke Kristen/Katolik lebih banyak terjadi lewat media pendidikan. Hal ini

\footnotetext{
${ }^{21}$ Wawancara dengan Drs. Sarjono, MM sebagai Pembimas Agama Buddha Kanwil Kemenag Provinsi Kalimantan Barat, 25 April 2015; Pendeta Ir. Iwan Luwuk sebagai Wakil Sekretaris
} 
terjadi karena di sekolah negeri hampir tidak ada guru Agama Buddha, sehingga siswa ikut ke ajaran lain ${ }^{22}$.

\section{E. Pembahasan}

\section{Aspek Majelis}

Struktur keorganisasian Majelis Agama Buddha Tantrayana Zhenfo Zong Kasogatan memiliki kecukupan sarana maupun prasarananya baik berkaitan dengan tempat ibadah (melalui keberadaan vihara), pembinaan umat Buddha (melalui peran para Bhikulama, Acarya maupun Maha Acarya) dan pembinaan anak-anak (melalui sekolah minggu) dan kesejahteraan umat Buddha (melalui peran lembaga otonom charity).

Masalah pendanaan merupakan hal yang dianggap penting bagi kelangsungan organisasi majelis beserta dengan beragam kegiatan pembinaan umat. Oleh sebab itu, aliran Tantrayana Zhenfo Zong Kasogatan sejauh ini dianggap berhasil dalam upaya mereka menggali beragam pendanaan baik yang bersifat usaha profit maupun non profit (dana paramitha). Cara yang digunakannya pun sangat sesuai dengan kebutuhan umat sehingga relatif tidak menghadapi kendala yang berarti.

\section{Aspek Potensi Konflik dan Penyelesaiannya}

Relasi sosial umat Buddha dengan non Buddha paling dekat terhadap umat Kristiani dan paling jauh dengan kalangan Muslim. Hal ini disebabkan oleh masalah makanan yang linier dengan keserbasalahan atau tidaknya bila melakukan perjamuan, tingkat kekhawatiran kehilangan identitas ketionghoannya yang dipersepsikan hilang, tidak setuju dengan sikap kekerasan (yang dialamatkan kepada beberapa ormas yang menggunakan kekerasan dalam menyelesaikan permasalahan).

Eksistensi Majelis Agama Buddha Tantrayana Zhenfo Zong Kasogatan Indonesia Kalimantan Barat ditunjukkan oleh tumbuh dan berkembangnya aliran ini di daerah penelitian.

FKUB Kota Pontianak/Pendeta Gereja Pantekosta Indonesia Barat Kota Pontianak, 24 April 2015.

${ }^{22}$ Wawancara dengan Drs. Sarjono, MM sebagai Pembimas Agama Buddha Kanwil Kemenag Provinsi Kalimantan Barat, 25 April 2015.
Masuknya aliran Kasogatan di Kalimantan Barat sampai sejauh ini masih mengikuti (dipengaruhi) perkembangan di tingkat pusat. Artinya bila perpecahan majelis terjadi di tingkat pusat maka akan mengakibatkan besarnya potensi terjadinya perpecahan juga di tingkat provinsi, kabupaten/ kota.

Beberapa konflik yang rawan muncul, yaitu: efek dari konversi agama yang tidak disetujui orang tua yang berpindah agama, kegiatan misionari (agama non Buddha) yang tidak didukung dengan etika dan masalah dalam pengajaran terhadap siswa beragama Buddha di sekolah yang tidak ada pengajar beragama Buddha.

Selama ini potensi konflik yang diakibatkan oleh perbedaan aliran dalam agama Buddha dapat diredam. Beberapa faktor penyebabnya, di antaranya: percaya karma dan percaya reinkarnasi sehingga masih ada kemungkinan terjadi perbaikan di masa kelahiran yang akan datang.

Adanya konflik dalam hal pengajaran maupun konflik terkait konversi agama selama ini belum terselesaikan dengan baik sehingga rawan terjadi eskalasi yang lebih tinggi di masa yang akan datang. Adapun masalah yang sudah tertangani hanya terkait kegiatan misionari yang tidak didukung etika yang penyelesaiannya dapat diselesaikan melalui musyawarah melibatkan tokoh dan pemerintah setempat.

\section{F. Penutup \\ Kesimpulan}

Berdasarkan paparan di atas dapat disebutkan beberapa kesimpulan sebagai berikut:

1. Secara umum kelahiran aliran Kasogatan merupakan sebuah harapan akan kebangkitan kembali agama Buddha di Indonesia (yakni pada zaman keprabuan Majapahit, zaman kedatuan Sriwijaya, serta pada zaman Mataram purba). Aliran ini di Indonesia dipelopori oleh mendiang Bhikkhu Ashin Jinnarakitta Mahathera pada tahun 1953. Pimpinan aliran Kasogatan di Kalimantan Barat bernama Herman Kora yang memimpin sejumlah manpower dengan berbagai fungsi, tugas dan dukungan sejumlah dana yang berasal dari donasi ummat maupun usaha otonom. Majelis Agama Buddha Tantrayana Zhenfo Zong Kasogatan sudah memiliki kecukupan sarana maupun 
prasarananya baik berkaitan dengan tempat ibadah, pembinaan umat Buddha dan pembinaan anak-anak dan kesejahteraan umat Buddha.

2. Penelitian ini tidak menemukan adanya konflik atau gesekan di antara majelis yang ada di Kalimantan Barat. Namun dalam hubungan ke luar, tercatat beberapa gesekan/ konflik yang terjadi yaitu: gesekan karena masalah pembakaran rupang, konflik dalam bidang pendidikan dan konflik akibat konversi agama. Relasi sosial umat Buddha dengan masyarakat masih terbatas pada bidang-bidang tertentu.

\section{Rekomendasi}

Penelitian ini sudah berupaya menjawab pertanyaan dengan semaksimal mungkin. Maka dari itu saran peneliti adalah :

1. Hasil penelitian ini secara umum kiranya dapat digunakan oleh Kementerian Agama RI, khususnya Direktorat Jenderal Bimbingan Masyarakat Buddha, sebagai bahan dalam menyusun kebijakan yang terkait dengan pembinaan keorganisasian lingkup agama Buddha.

2. Menyangkut hubungan antaragama, di Kalimantan Barat khususnya pemeluk agama Buddha aliran Kasogatan dengan Kristiani mengalami konflik (meskipun masih dalam tahap prasangka) pada aktivitas efek konversi agama, pendidikan keagamaan Buddha dan kegiatan misionari (agama) yang tidak didukung dengan etika. Maka dari itu perlu dilakukan pengawasan dan pembinaan di daerah melalui perangkat penyelenggara bimbingan masyarakat Buddha dan Pembimas Buddha.[] 
Alfian. 2009. "Sekte-Sekte dalam Agama Buddha". Dalam http://jayalah-indonesiakutercinta.blogspot.com/2009/09/sekte-sektedalam-agama-buddha.htm?m=1 [Diunduh 30 Februari 2015].

Buddha Dharma Education Association. 2008. "Buddhism in Indonesia". dalam http:// www.buddhanet.net/e-learrning/ buddhistworld/indo-txt.htm [Diunduh 23 April 2015].

Sumedha Widyadharma, 1995. "Agama Buddha dan Perkembangannya di Indonesia". Dalam http://www.samaggi-phala.or.id/ naskah-dhamma/agama-buddha-danperkembangannya-di-indonesia/ [Diunduh 3 dan 23 Maret 2015].
SVD, Bernard Raho. Agama dalam Perspektif Sosiologi. Jakarta: Penerbit Obor, 2013.

Idrus, Muhammad. Metode Penelitian Ilmu Sosial : Pendekatan Kualitatif dan Kuantitatif. Jakarta: Erlangga, 2009.

Nuh, Nuhrison M. Respon Masyarakat terhadap Aliran dan Paham Keagamaan Kontemporer di Indonesia. Jakarta: Puslitbang Kehidupan Keagamaan, Badan Litbang dan Diklat, Kementerian Agama RI, 2012. 
